\title{
Histopatologi Hati dan Usus Ikan Jambal Siam (Pangasionodon hypophthalmus) yang Diberi Pakan Mengandung Ekstrak Daun Rhizophora apiculata
}

\author{
Histopathology of Liver and Intestine of Pangasionodon hypophthalmus Fed with \\ Rhizophora Apiculata Enriched Pellets
}

\author{
Abdul Alif ${ }^{*}$, Henni Syawal ${ }^{1}$, Morina Riauwaty ${ }^{1}$ \\ ${ }^{1}$ Jurusan Budidaya Perairan, Fakultas Perikanan dan Kelautan, Universitas Riau \\ email:abdul.alif@student.unri.ac.id
}

(Received: 10 Juni 2021; Accepted: 01 Juli 2021)

\begin{abstract}
ABSTRAK
Daun bakau $R$. apiculata memiliki senyawa bioaktif berupa flavonoid, tanin, saponin, dan quinon yang mempunyai daya antioksidan, antibakteri dan antiinflamasi. Penelitian ini telah dilaksanakan pada bulan Agustus sampai November 2019 di Fakultas Perikanan dan Kelautan Universitas Riau. Tujuan dari penelitian ini adalah untuk menganalisis histopatologi hati dan usus ikan jambal siam ( $P$. hypophthalmus) yang diberi pakan mengandung ekstrak daun $R$. apiculata. Metode yang digunakan adalah eksperimen dengan Rancangan Acak Lengkap (RAL) satu faktor 4 taraf perlakuan 3 ulangan. Perlakuan yang digunakan adalah kontrol tanpa penambahan ekstrak daun $R$. apiculata $\left(\mathrm{P}_{0}\right)$, dan pemberian pakan dengan tambahan ekstrak daun $R$. apiculata dosis 1,5 $\mathrm{mg} / \mathrm{Kg}\left(\mathrm{P}_{1}\right), 1,7 \mathrm{mg} / \mathrm{Kg}\left(\mathrm{P}_{2}\right)$ dan $1,9 \mathrm{mg} / \mathrm{Kg}\left(\mathrm{P}_{3}\right)$ pakan. Ikan yang digunakan berukuran $8-10 \mathrm{~cm}$ dan dipelihara di waduk. Pemberian pakan dilakukan sebanyak 10\% dari bobot biomassa ikan dengan frekuensi pemberian sebanyak 3 kali selama 60 hari pemeliharaan. Organ sampel difiksasi menggunakan formalin 10\%. Preparat histologi dengan pewarnaan HE. Hasil penelitian menunjukkan bahwa pemberian pakan mengandung ekstrak daun $R$. apiculata berpengaruh terhadap perubahan histologis hati dan usus ikan jambal siam. Perubahan yang terjadi pada hati ikan yaitu hemoragi, hipertropi dan nekrosis, sedangkan pada usus terjadi perubahan histologis berupa hemoragi, edema, proliferasi sel goblet, degenerasi vakuola dan nekrosis. Dosis terbaik terdapat pada $\mathrm{P}_{1}$ yaitu sebesar $1,5 \mathrm{mg} / \mathrm{Kg}$ pakan. Parameter kualitas air selama penelitian yaitu suhu 28-29.5 ${ }^{0}$; pH 6,1-6,8; DO 6,4-6,9ppm; dan $\mathrm{NH}_{3}$ 0,04-0,08ppm.
\end{abstract}

Kata Kunci: Histopatologi, Hati, Usus, Rhizophora, Jambal Siam

\begin{abstract}
Rhizohora apiculata leaves contain flavonoids, tannins, saponins, and quinones which have antioxidant, antibacterial and anti-inflammatory power. This research was conducted from August to November 2019 at the Fisheries and Marine Faculty, Riau University. The purpose of this study was to analyze the liver and intestinal histopathology of $P$. hypophthalmus which was fed with pellet enriched $R$. apiculata leaf extract. The method used was an experiment with a completely randomized design (CRD) one factor 4 treatment levels 3 replications. The treatments used were control without the addition of $R$. apiculata leaf extract $\left(\mathrm{P}_{1}\right)$, and pellet enriched with additional $R$. apiculata leaf extract at a dose of $1.5 \mathrm{mg} / \mathrm{Kg}\left(\mathrm{P}_{1}\right), 1.7 \mathrm{mg} / \mathrm{Kg}\left(\mathrm{P}_{2}\right)$ and $1.9 \mathrm{mg} / \mathrm{Kg}\left(\mathrm{P}_{3}\right)$ feed. The fishes used are $8-10 \mathrm{~cm}$ in size and reared in the reservoir. Fishes were fed $10 \%$ of the fish biomass 3 times a day for 60 days pisciculture. The sample organs were preserved using $10 \%$ formalin. Histological preparations with HE staining. The results showed that fish feed enriched with $R$. apiculata leaf extract had an effect on histological changes in the liver and intestines of $P$. hypophthalmus. The abnormalities in fish liver were hemorrhage, hypertrophy and necrosis, while in the intestine there are histological changes in the form of hemorrhage, edema, goblet cell proliferation, vacuole degeneration and necrosis. The best dose is found in $\mathrm{P} 1$, which is $1.5 \mathrm{mg} / \mathrm{Kg}$
\end{abstract}


of feed. Water quality parameters during the study were temperature 28-29.50C; $\mathrm{pH}$ 6.1-6.8; DO 6.4-6.9ppm; and $\mathrm{NH}_{3} 0.04-0.08 \mathrm{ppm}$.

Keyword: Histopathology, Liver, Intestine, Rhizophora, Catfish

\section{Pendahuluan}

Ikan jambal siam (Pangasianodon hypophthalmus) merupakan jenis ikan konsumsi air tawar yang memiliki rasa daging yang enak, gurih dan lezat sehingga digemari oleh masyarakat. Dalam intensifikasi budidaya biasanya terdapat kendala berupa penyakit yang biasanya diatasi pembudidaya menggunakan antibiotik. Namun penggunaan antibiotik secara terus menerus dan dosis yang tidak tepat dapat berdampak negatif terhadap lingkungan perairan dan menimbulkan resistensi pada bakteri (Syawal et al., 2018). Untuk itu perlu dicarikan alternatif lain, yakni bahan alami

Tanaman bakau Rhizophora dapat digunakan sebagai senyawa antibakteri khususnya bagian batang dan daun karena mengandung senyawa alkaloid, saponin, flavonoid dan tanin yang merupakan senyawa antibakteri (Rohaeti, 2010). Menurut Suciati et al. (2012), ekstrak daun Rhizophora efektif dalam menghambat pertumbuhan bakteri patogen. Selain itu, ekstrak dari tumbuhan R.apiculata menurut Ramalingam dan Rajaram (2018) memiliki potensi menjadi antioksidan dan zat antikanker. Masyarakat pesisir sering menggunakan Rhizopora apiculata sebagai obat anti diare, obat mual, muntah, antiviral dan hypoglikemik (Berawi dan Desty, 2018).

Namun kandungan $R$. apiculata juga memiliki sifat toksik terhadap ikan (Apriyanto et al., 2014). Penggunaan bahan alami juga memiliki efek samping pada hati dan usus ikan. Seperti pada pemberian pakan ikan mengandung simplisia kulit buah manggis menyebabkan kerusakan berupa sel radang, haemoragi, hiperthropy dan nekrosis pada hati ikan lele (Kahfi et al., 2016). Dewi (2018) dalam hasil penelitiannya menunjukkan perendaman ikan nila pada ekstrak buah mengkudu menyebabkan adanya perubahan struktur jaringan hati ikan yang diuji. Penggunaan tepung kedelai dalam pakan menyebabkan perubahan histopatologis dalam usus seperti terjadinya infiltrasi sel imun ringan, penumpulan villi, fusi villi, infiltrasi sel imun mononuklear, serta nekrosis
(Sohrabnezhad et al., 2017). Hati dan usus merupakan organ yang memiliki peranan penting dalam proses pencernaan dan rawan mengalami kerusakan. Kerusakan yang terjadi pada hati dan usus ikan dapat diamati dengan metode pemeriksaan histologi.

Berdasarkan informasi mengenai potensi dari ekstrak Rhizophora yang mampu dijadikan imunostimulan alami serta adanya pengaruh pemberian bahan alami pada histopatologi hati dan usus ikan maka dari itu penulis tertarik untuk melakukan penelitian mengenai pengaruh pemberian pakan mengandung ekstrak daun $R$. apiculata terhadap histologi usus dan hati ikan jambal siam (P.hypophthalmus).

\section{Metode Penelitian}

\subsection{Waktu dan Tempat}

Penelitian ini dilaksanakan pada bulan Agustus sampai November 2019 di Fakultas Perikanan dan Kelautan Universitas Riau.

\subsection{Metode Penelitian}

Metode yang digunakan dalam penelitian ini adalah metode eksperimen dengan Rancangan Acak Lengkap (RAL) satu faktor dengan 4 taraf perlakuan dan ulangan sebanyak 3 kali. Adapun perlakuan yang diterapkan adalah sebagai berikut:

$$
\begin{array}{rlr}
\mathrm{P} 0= & \begin{array}{l}
\text { Kontrol (Pemberian pakan } \\
\text { penambahan ekstrak }
\end{array} & \begin{array}{r}
\text { tanpa } \\
\text { daun }
\end{array} \\
\mathrm{P} 1= & \begin{array}{l}
\text { R.apiculata } \\
\text { Penambahan ekstrak }
\end{array} \\
& \begin{array}{l}
\text { R.apiculata dengan dosis } 1,5 \mathrm{mg} / \mathrm{kg} \\
\text { pakan. }
\end{array} \\
\mathrm{P} 2= & \begin{array}{l}
\text { Penambahan ekstrak daun } \\
\end{array} \\
& \begin{array}{l}
\text { R.apiculata dengan dosis } 1,7 \mathrm{mg} / \mathrm{kg} \\
\text { pakan }
\end{array} \\
\mathrm{P} 3= & \begin{array}{l}
\text { Penambahan ekstrak daun } \\
\text { R.apiculata dengan dosis } 1,9 \mathrm{mg} / \mathrm{kg}
\end{array} \\
& \text { pakan }
\end{array}
$$

\subsection{Prosedur Penelitian}

\subsubsection{Pembuatan Ekstrak Daun R.apiculata \\ Daun $R$. apiculata yang digunakan} adalah daun yang berada pada bagian ujung 
urutan daun ke-1 sampai daun ke-5 yang dicuci bersih dan diiris tipis-tipis, kemudian dikeringanginkan selama dua minggu pada suhu ruangan. Daun yang sudah kering dihaluskan menggunakan blender, untuk selanjutnya dimaserasi. Maserasi dilakukan dengan cara merendam daun $R$. apiculata yang telah dihaluskan dalam pelarut etanol $96 \%$ dengan perbandingan $1: 5$, yang berarti $1 \mathrm{~kg}$ daun $R$. apiculata direndam dengan $5 \mathrm{~L}$ etanol $96 \%$. Wadah penyimpanan kemudian ditutup rapat agar larutan etanol tidak menguap. Proses maserasi dilakukan pada suhu ruang selama 24 jam. Setelah didiamkan selama 24 jam sampel disaring menggunakan kain kasa untuk memperoleh filtrat dan residu. Kemudian dilakukan remaserasi (perendaman kembali menggunakan pelarut dengan cara yang sama) terhadap residu sebanyak 3 kali pengulangan. Filtrat yang dihasilkan ditampung menjadi satu dan dievaporasi menggunakan alat Rotary Evaporator untuk proses penguapan atau pemurnian ekstrak daun $R$. apiculata dari pelarut etanol $96 \%$ pada suhu $60^{\circ} \mathrm{C}$ dan kecepatan $60-90 \mathrm{rpm}$ hingga pelarut habis menguap dan diperoleh ekstrak daun $R$. apiculata (ekstrak murni) berupa gel dan etanol murni (Handayani, 2013). Setelah didapatkan ekstrak murni daun $R$. apiculata maka setelahnya dilakukan proses partisi.

Partisi menggunakan pelarut heksan dan ethyl asetat. Ekstrak daun R.apiculata dipartisi menggunakan heksan sebanyak 300 $\mathrm{mL}$ di dalam tabung corong pisah berukuran 2L, kemudian hasil dari partisi pelarut heksan dipartisi kembali menggunakan pelarut ethyl asetat sebanyak $300 \mathrm{~mL}$ di dalam tabung corong pisah berukuran 2L. Hasil partisi ethyl asetat kemudian dievaporasi menggunakan alat Rotary Evaporator dengan suhu $60^{\circ} \mathrm{C}$ dan kecepatan 60-90 rpm, hingga terbentuk gel. Lalu ditutup dengan plastik aseptik, kemudian di atasnya dibolongi dan disimpan dalam kulkas hingga gel mengering

\subsubsection{Persiapan Pakan yang Mengandung Ekstrak Daun R.apiculata}

Pembuatan pakan dimulai dengan menentukan komposisi masing-masing bahan sesuai dengan kebutuhan protein yang diharapkan, yaitu sebesar 35\%. Proporsi ekstrak daun $R$. apiculata ditentukan sesuai kebutuhan masing-masing perlakuan, sedangkan bahan-bahan lain seperti tepung ikan, tepung kedelai, tepung terigu, vitamin mix, mineral mix serta minyak ikan disesuaikan jumlahnya berdasarkan hasil perhitungan. Bahan-bahan yang digunakan ditimbang sesuai kebutuhan.

\subsubsection{Pemeliharaan Ikan}

Ikan yang digunakan berukuran 8-10 $\mathrm{cm}$ dipelihara di keramba jaring tancap dengan padat tebar $50 \mathrm{ekor} / \mathrm{m}^{3}$. Jumlah pakan yang diberikan $10 \%$ dari biomassa ikan dengan frekuensi pemberian pakan sebanyak 3 kali sehari pada pukul $08.00,12.00$, dan 16.00 WIB selama 60 hari pemeliharaan.

\subsubsection{Pengukuran Kualitas Air}

Parameter kualitas air yang diukur selama penelitian adalah suhu yang diukur menggunakan thermometer, $\mathrm{pH}$ diukur menggunakan $\mathrm{pH}$ meter, oksigen terlarut (DO) yang diukur menggunakan DO meter dan amonia $\left(\mathrm{NH}_{3}\right)$ yang diukur menggunakan spektrofotometer pengukuran dilakukan pada awal dan akhir penelitian.

\subsubsection{Pembuatan Preparat Histologi}

Organ hati dan usus ikan difiksasi dalam larutan formalin $10 \%$. Setelah dilakukan fiksasi pada organ, selanjutnya dilakukan proses dehidrasi untuk mengeluarkan formalin dari jaringan. Dehidrasi dimulai dengan memasukkan sampel ke dalam alkohol seri naik mulai dari 35\%, 70\%, 80\%, 90\% dan alkohol absolut masing-masing selama 1 jam.

Penjernihan (Clearing) dilakukan dengan sampel dimasukkan ke dalam alkoholXylol (1:1) selama 1 jam dan dimasukkan ke dalam Xylol I dan Xylol II masing-masing 1 jam. Selanjutnya dilakukan proses infiltrasi paraffin. Infiltrasi paraffin dilakukan dengan cara sampel dimasukkan ke dalam campuran Xylol-parafin (1:1) selama 1 jam. Kemudian sampel dimasukkan ke dalam paraffin murni 1 dan parafin murni 2 masing-masing selama 1 jam. Seluruh proses infiltrasi dilakukan di tissue embedding center pada suhu $56^{\circ} \mathrm{C}$. Kemudian penanaman sampel (Embedding).

Penanaman sampel (Embedding) dilakukan dengan cara sampel ditanam dalam blok parafin pada suhu $62^{\circ} \mathrm{C}$ kemudian ditutup dengan tissue cassette dan dibiarkan hingga dingin/mengeras pada freezer selama 2 sampai 24 jam. Sebelum dipotong blok 
parafin ditempatkan pada balok es agar tidak mencair dan tidak pecah saat pemotongan.

Tahap selanjutnya adalah Sectioning dan proses pemotongan (cutting) sampel menggunakan mikrotom Sampel diletakkan pada holder mikrotom kemudian dirapikan dan dipotong dengan ketebalan 5 mikron. Pita parafin yang berisi sampel ditempatkan ke dalam water bath dengan suhu $45^{\circ} \mathrm{C}$. Setelah sampel mengembang kemudian diambil dan ditempelkan ke dalam objek glass yang sudah diolesi glyserin-albumin. Selanjutnya sampel diinkubasi dalam oven pada suhu $45^{\circ} \mathrm{C}$ selama 24 jam. bagan pembuatan preparat histologi dapat dilihat pada Lampiran 5. Kemudian dilakukan pewarnaan sampel.

Pewarnaan sampel menggunakan larutan HE (Hematoxylin-Eosin). Hematoxylin akan mewarnai nukleus menjadi berwarna biru keunguan dan eosin akan mewarnai sitoplasma berwarna merah mendekati pink. Parafin yang mengikat sampel dilarutkan dalam Xylol I, Xylol II dan Xylol III masing-masing 3 menit dan selanjutnya dilakukan rehidrasi dalam alkohol seri turun (alkohol absolut I, absolut II, 96\% I, 96\% II, 80\%) masing-masing 3 menit dan dicuci dengan air mengalir 3 menit. Kemudian sampel direndam dalam larutan hematoxylin selama 6-8 menit, kemudian dicuci dengan air mengalir secukupnya. Selanjutnya sampel direndam dalam eosin selama 6-8 menit, sesudah itu sampel dicuci dengan air mengalir secukupnya sampai bening. Kemudian sampel dicelupkan dalam alkohol seri naik (alkohol $80 \%, 90 \%$, alkohol absolut I, alkohol absolut II) masing-masing 10 celupan dan direndam dalam Xylol I, Xylol II, Xylol selama masingmasing 5 menit. Selanjutnya dilakukan penutupan (mounting). bagan pewarnaan preparat dapat dilihat pada Lampiran 6.

Penutupan (mounting) dilakukan dengan cara menutup sampel dengan cover glass. Sampel ditetesi dengan entellan neu kemudian ditutupi dengan cover, setelahnya diinkubasi dalam oven dengan suhu $45^{\circ} \mathrm{C}$. Sampel yang sudah selesai diamati menggunakan mikroskop binokuler dengan pembesaran 400x dan gambar diambil menggunakan kamera digital.

\subsection{Analisis Data}

Hasil penelitian ini berupa preparat histologi hati dan usus ikan jambal siam. Data diambil dengan melihat perubahan yang terdapat pada hati dan usus ikan jambal siam dengan menggunakan mikroskop binokuler. Tingkat kerusakan dan kelainan yang terjadi pada jaringan hati dan usus ikan jambal siam dihitung dan dikategorikan berdasarkan penilaian Histological Alteration Index (HAI) dan dianalisis secara deskriptif.

\section{Hasil dan Pembahasan}

\subsection{Histologi Hati Ikan Jambal Siam}

Hati ikan jambal siam terletak di perut sekitar usus bagian depan tepat di belakang jantung. Organ ini memiliki warna merah kecoklatan. Organ ini berfungsi sebagai penjaga homeostatis metabolisme, penyimpan nutrien dan detoksifikasi pada ikan. Hati merupakan pusat metabolisme tubuh, organ hati menghasilkan cairan empedu sebagai emulsifikator lemak yang berperan penting dalam proses pencernaan makanan (Safratilofa, 2017). Hati rawan mengalami kerusakan berkaitan dengan fungsi hati dalam detoksifikasi zat toksik. Permana (2009) menyatakan, faktor utama penyebab kerusakan karena hati dilewati darah yang dibawa dari seluruh tubuh terutama sistem pencernaan yang rentan membawa zat polutan.

Sel parenkim hati atau yang disebut sel hepatosit terletak diantara sinusoid yang berisi darah dan saluran empedu (Safratilofa, 2017). Sel hati pada umumnya berbentuk polihedral dengan enam permukaan atau lebih dengan inti berbentuk bulat dengan banyak retikulum endoplasma. Pada keadaan normal sel hepatosit berbentuk bulat dan sinusoid terlihat jelas (Riauwaty, 2012).

Berdasarkan hasil pengamatan terhadap histopatologi hati ikan jambal siam menunjukkan adanya perubahan setelah diberi pakan mengandung ekstrak daun $R$. apiculata. $\mathrm{P}_{0}$ merupakan perlakuan kontrol menunjukkan struktur hati ikan jambal siam normal, pada $\mathrm{P}_{1}$ hanya terlihat kerusakan berupa hemoragi. Pada $\mathrm{P}_{2}$ dan $\mathrm{P}_{3}$ terlihat kerusakan berupa hemoragi, hipertropi dan nekrosis. Kerusakan pada hati ikan jambal siam setelah diberi perlakuan berupa penambahan ekstrak daun $R$. apiculata dapat dilihat pada Gambar 1. dan tingkat kerusakan dapat dilihat pada Tabel 2. $\mathrm{P}_{1}$ memiliki tingkat kerusakan 2 dan dikategorikan golongan normal. $\mathrm{P}_{2}$ dengan tingkat kerusakan 3 dan $\mathrm{P}_{3}$ dengan tingkat 
kerusakan sebesar 4 dikategorikan dengan hati

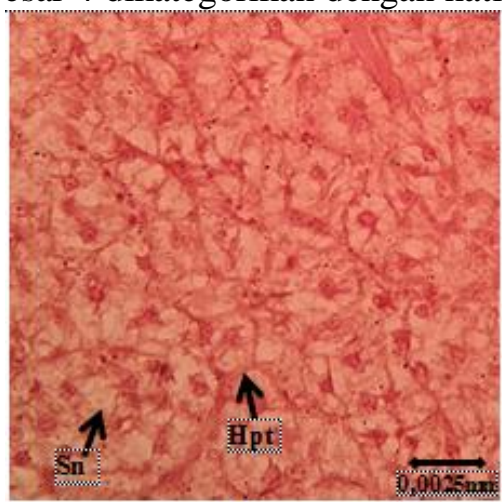

$\mathbf{P}_{0}$

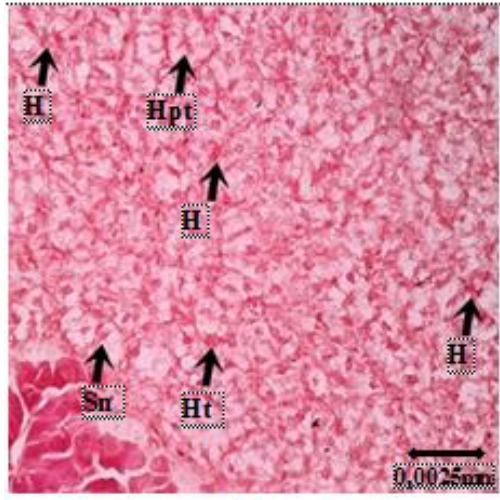

$P_{2}$ yang rusak (Windarti et al., 2017).

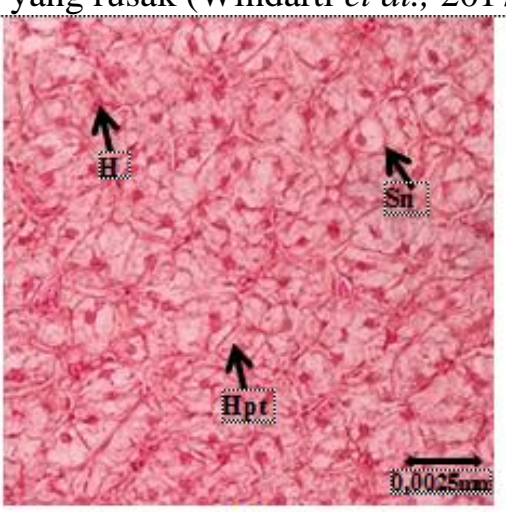

$\mathbf{P}_{1}$

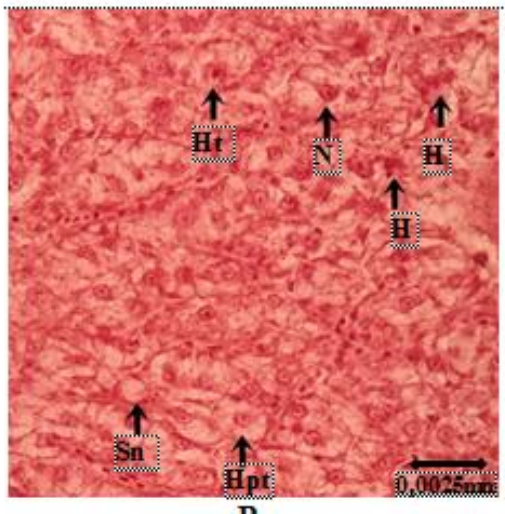

$\mathbf{P}_{3}$

Gambar 1. Fotomikrogaf Struktur Hati Ikan Jambal Siam (P. hypophthalmus) pewarnaan HE (Perbesaran 400X)

Keterangan: $\mathrm{P}_{0}=$ Pemberian pakan tanpa tambahan ekstrak daun $R$. apiculata; $\mathrm{P}_{1}=1.5 \mathrm{mg} / \mathrm{Kg}$ pakan; $\mathrm{P}_{2}=1.7 \mathrm{mg} / \mathrm{Kg}$ pakan; $\mathrm{P}_{3}=1.9 \mathrm{mg} / \mathrm{Kg}$ pakan. $\mathrm{H}$ (Hemoragi); Ht (Hipertropi); N (Nekrosis); hpt (Hepatosit); sn (Sinusoid).

Tabel 1. Kerusakan Hati Ikan Jambal Siam (P. hypophthalmus) Berdasarkan Indeks yang Dimodifikasi dari Pierce et al. dalam Windarti et al., (2017).

\begin{tabular}{clcccc}
\hline \multirow{2}{*}{ No } & \multirow{2}{*}{ Kerusakan } & \multicolumn{4}{c}{ Perlakuan } \\
\cline { 2 - 6 } & Hemoragi & $\mathbf{P}_{\mathbf{0}}$ & $\mathbf{P}_{\mathbf{1}}$ & $\mathbf{P}_{\mathbf{2}}$ & $\mathbf{P}_{\mathbf{3}}$ \\
\hline $\mathbf{1}$ & Hipertropi & - & + & + & + \\
$\mathbf{2}$ & Nekrosis & - & - & + & + \\
$\mathbf{3}$ & Tingkat kerusakan & - & - & - & + \\
\hline & & $\mathbf{0}$ & $\mathbf{2}$ & $\mathbf{3}$ & $\mathbf{4}$ \\
\hline
\end{tabular}

Keterangan: (+) Ditemukan; (-) Tidak Ditemukan

Hemoragi ditemukan pada semua perlakuan. Hemoragi merupakan keluarnya darah dikarenakan pembuluh darah yang rusak. Jamin dan Erlangga (2016) menyatakan bahwa hemoragi merupakan pendarahan pada sel yang diakibatkan oleh pecahnya pembuluh darah sehingga menyebabkan darah mengalir pada tempat yang tidak semestinya baik ke luar tubuh maupun ke dalam jaringan tubuh. Hemoragi pada histopatologi yang diamati terlihat dengan adanya bintik merah pekat atau hitam. Tanda ini sesuai dengan yang dinyatakan Andayani et al. (2018), dimana hemoragi ditandai dengan adanya bintik darah pada pembuluh darah jaringan tubuh yang diakibatkan kongesti pada hati sudah sangat parah sehingga menyebabkan pembuluh darah menjadi rusak. Kandungan pada ekstrak tumbuhan pada umumnya dalam penggunaan jumlah banyak akan berakibat negatif pada organisme salah satunya adalah hemoragi. Diba dan Wildan (2018) menyatakan paparan toksik akut, adanya bakteri, virus dan parasit 
dapat menyebabkan terjadinya kerusakan hemoragi.

Hipertropi terlihat di $\mathrm{P}_{2}$ dan $\mathrm{P}_{3}$. Hipertropi yang ditemukan ditandai dengan adanya hepatosit yang membesar. Jamin dan Erlangga (2016) menyatakan, hipertropi merupakan sel yang membengkak akibat bertambahnya ukuran hingga menyebabkan sel saling lepas satu sama lainnya. Kerusakan hipertropi disebabkan oleh dosis $R$. apiculata yang diberikan lebih banyak dibandingkan yang bisa dimanfaatkan oleh ikan. Hal ini menyebabkan kandungan R.apiculata memberikan efek negatif berupa hipertropi. Pembengkakan sel terjadi karena muatan elektrolit di luar dan di dalam sel berada dalam keadaan tidak setimbang, menyebabkan peningkatan masuknya cairan dari ektraseluler ke dalam sel sehingga sel tidak mampu memompa cukup ion natrium ke luar (Sukarni dan Happy, 2012).

Kerusakan nekrosis ditemukan pada $\mathrm{P}_{3}$, perlakuan dengan pemberian dosis ekstrak yang paling besar. Nekrosis merupakan sel yang mengalami kematian atau kerusakan dengan aktivitas yang sangat rendah. Pada umumnya kerusakan ini tidak dapat diperbaiki atau bersifat irreversibel. Hal ini sesuai dengan Yanti (2018), kerusakan ini bersifat irreversibel yaitu tidak dapat diperbaiki. Menurut Asniatih et al. (2013), inti sel dan sitoplasma pada hati yang mengalami nekrosis sudah tidak jelas atau tidak terlihat sama sekali.

Kerusakan nekrosis dapat disebabkan oleh berbagai faktor, diantaranya adalah faktor lingkungan, patogen, makanan, dan zat lain yang masuk ke dalam tubuh ikan. Luka berat, lamanya hati mengalami luka, terpapar zat toksik ataupun organisme infeksius maka sel hati akan sulit beradaptasi sehingga nekrosis pada sel hati akan meningkat. Gangguan enzimatis dan molekuler pada sel diduga dapat memperparah keadaan nekrosis pada hati. Nekrosis tidak terjadi pada $P_{1}$ dikarenakan kandungan flavonoid $R$. apiculata pada dosis yang rendah mampu mencegah terjadinya gangguan enzimatis. Arnanda dan Rina (2019), menyatakan flavonoid mampu menjadi inhibitor enzim pembentukan radikal bebas. Nazarudin et al. (2017) menyatakan bahwa nekrosis merupakan hasil interaksi antara radikal bebas hasil metabolisme obat dan metabolisme tubuh dengan biomolekul penyusun membaran sel hati.

Menurut Ciptaningrum dan Reyhan (2019), tumbuhan bakau $R$. apiculata mengandung senyawa bioaktif, diantaranya senyawa golongan alkaloid, steroid, tanin, saponin, terpenoid serta senyawa golongan flavonoid dan quinon. Darlian et al. (2011) menyatakan bahwa kandungan yang penting yang dihasilkan dari tumbuhan $R$. apiculata ini yaitu flavonoid, tanin dan saponin Kandungan tersebut merupakan senyawa bioaktif yang memiliki nilai antioksidan yang tinggi namun juga bersifat toksik. Antioksidan mampu menghilangkan, membersihkan, menahan dan menangkal pembentukan reaksi oksidasi yang disebabkan radikal bebas dalam tubuh sehingga kerusakan pada sel dapat dihindari.

Pengaruh penggunaan ekstrak R.apiculata sebagai bahan tambahan di dalam pakan dapat dilihat pada $\mathrm{P}_{1}$ dimana kerusakan lebih sedikit. Selain antioksidan, kandungan dari $R$. apiculata ini berperan dalam mencegah berkembangnya mikroba, senyawa penyembuhan, antiseptik dan zat antiinflamasi. Namun pemberian dosis yang berlebihan pada organisme dapat menyebabkan efek samping pada organisme, sebagaimana Marlinda (2012) menyatakan bahwa senyawa aktif dalam tumbuhan selalu bersifat toksik pada pemberian dosis tinggi. Senyawa tersebut diantaranya adalah tanin dan saponin.Winarsih (2012) menambahkan bahwa kerusakan pada hati menunjukkan perubahan yang semakin parah sejalan dengan peningkatan dosis bahan alami yang diberikan.

$R$. apiculata memiliki sejumlah kandungan bioaktif, salah satunya adalah flavonoid. Flavonoid memiliki kemampuan antioksidan yang dapat mencegah proses oksidasi sehingga tidak terjadi kerusakan pada sel. Redha (2010), menyatakan bahwa flavonoid memiliki aktivitas biologis sebagai antialergik, antiviral, dan antiinflamasi yang dapat mencegah terjadinya peradangan pada jaringan sehingga mencegah terjadi kerusakan seperti hemoragi dan nekrosis. Flavonoid juga dinyatakan mampu mencegah terjadinya perlemakan pada sel sehingga dapat menghentikan efek lanjutan berupa nekrosis dan hipertropi. Namun pada dosis yang berlebihan, flavonoid dapat menjadi penyebab 
rusaknya dinding sel yang mengakibatkan kerusakan hemoragi dan nekrosis.

Kerusakan pada $\mathrm{P}_{2}$ dan $\mathrm{P}_{3}$ diduga karena jumlah ekstrak yang diberikan melebihi apa yang dibutuhkan oleh ikan sehingga memberikan efek negatif pada struktur jaringan hati ikan. Kandungan senyawa bioaktif dalam dosis yang melebihi batas dan pemaparan yang cukup lama dapat menjadikan sifat antinutrien dan toksik pada ikan yang mengkonsumsi. Sesuai dengan yang dinyatakan oleh Winarsih et al. (2012), apabila paparan zat toksik pada sel cukup hebat atau berlangsung cukup lama, maka dapat menimbulkan kematian sel/nekrosis.

Pakan yang mengandung tanin berlebih dapat menyebabkan naiknya tingkat oksidatif pada organ sehingga menjadi salah satu faktor kerusakan yang terjadi pada hati ikan. Sebagaimana dinyatakan oleh Wiranatha $e t$ al. (2019), dimana paparan tanin dalam waktu lama dan jumlah besar dapat menjadi antinutrien berbahaya, menyebabkan degenerasi lemak pada hepatosit yang berakibat terjadinya nekrosis, dan meningkatnya radikal bebas sehingga memicu stress oksidatif yang menyebabkan kerusakan pada sel. Begitu juga dengan kandungan saponin yang berlebih dapat menjadi racun pada tubuh organisme yang mengkonsumsi. Kinasih (2013) menyatakan bahwa saponin merupakan racun bagi organisme poikiloterm karena dapat menghemolisis sel darah merah sehingga menyebabkan ikan kesulitan dalam mengalirkan oksigen yang dapat mendorong kematian sel.

\subsection{Histologi Usus Ikan Jambal Siam}

Usus merupakan saluran pencernaan terpanjang pada ikan. Panjang usus dimulai dari pilorik sampai ke anus. Aanyu et al. (2014) menyatakan bahwa perubahan histologi pada usus dapat memberikan gambaran kemampuan ikan dalam mencerna makanan dan efek yang ditimbulkannya. Kerusakan pada usus dapat disebabkan oleh mikroba, patogen dan zat toksik yang masuk ke dalam usus. Diba dan Wildan (2018) menyatakan bahwa patogen dapat masuk secara oral ke dalam usus, terkhusus melalui makanan yang dimakan oleh ikan. Pada keadaan normal usus ikan terdiri atas lapisan mukosa, sub mukosa, muskularis dan membran serosa.
Perubahan histologi yang terjadi pada usus ikan jambal siam yang diamati antara lain adalah Pada $\mathrm{P}_{1}$ terlihat kerusakan berupa degenerasi vakuola, edema, proliferasi sel goblet dan nekrosis. Pada $\mathrm{P}_{2}$ terlihat terjadi perubahan berupa hemoragi, edema, degenerasi vakuola dan nekrosis. Pada $\mathrm{P}_{3}$ terjadi kerusakan jenis proliferasi sel goblet yang diiringi dengan nekrosis dan degenerasi vakuola. Histologi usus ikan hasil penelitian ditunjukkan pada Gambar 3.

Hemoragi pada usus ditunjukkan dengan adanya bagian merah pekat pada histologi usus yang diamati yang banyak terjadi pada bagian sub mukosa usus. Menurut Juanda dan Sri, (2018) hemoragi pada usus menandakan adanya eritrosit yang sudah keluar dari pembuluh darah dan berada di jaringan usus. Saponin merupakan salah satu senyawa yang dapat menyebabkan kerusakan pada epitel usus yang mengakibatkan terjadinya hemoragi pada dinding sel. Atmoko dan Amir (2009) menyatakan bahwa saponin dapat menurunkan tegangan permukaan selaput saluran pencernaan sehingga dinding saluran pencernaan menjadi rusak. Kerusakan ini banyak terlihat pada $\mathrm{P}_{2}$ dan $\mathrm{P}_{3}$.

Edema pada usus ikan terlihat dengan adanya pembengkakan jaringan yang berisi cairan. Ismaya et al. (2017) menjelaskan bahwa edema merupakan keadaan dimana jumlah cairan pada kompartemen intraseluler mengalami peningkatan. Edema dikarenakan terganggunya permeabilitas sel pada jaringan usus. Selain patogen dan mikroba, kandungan ekstrak $R$. apiculata dikonsumsi ikan dapat mengganggu permeabilitas sel. Kandungan flavonoid dan tanin yang berlebih dapat menyebabkan denaturasi protein dan peningkatan permeabilitas sel. Menurut Adila et al. (2013) senyawa flavonoid mampu merusak dinding sel sehingga menyebabkan kematian sel. Flavonoid bekerja dengan cara denaturasi protein dan terjadi peningkatan permeabilitas membaran sitoplasma. Menurut Ciptaningrum dan Reyhan (2019), tanin mempunyai sifat pengelat plasmolitik yang dapat mengerutkan membran sel sehingga mengganggu permeabilitas sel, kemudian sel tidak dapat melakukan aktivitas hidup sehingga pertumbuhannya terhambat atau bahkan mati.

Nekrosis pada usus ditemukan paling parah pada perlakuan $\mathrm{P}_{2}$ dan $\mathrm{P}_{3}$. Nekrosis 
ditandai dengan adanya jaringan usus yang rusak. Kerusakan nekrosis dapat disebabkan karena kandungan $R$. apiculata memiliki senyawa bioaktif dari tumbuhan yang mana dalam penggunaan dalam dosis besar dan waktu lama dapat menyebabkan terjadinya nekrosis pada organ. Herawati et al. (2009) menyatakan bahwa tanin merupakan salah satu senyawa polifenol yang banyak ditemukan pada tumbuhan mangrove family
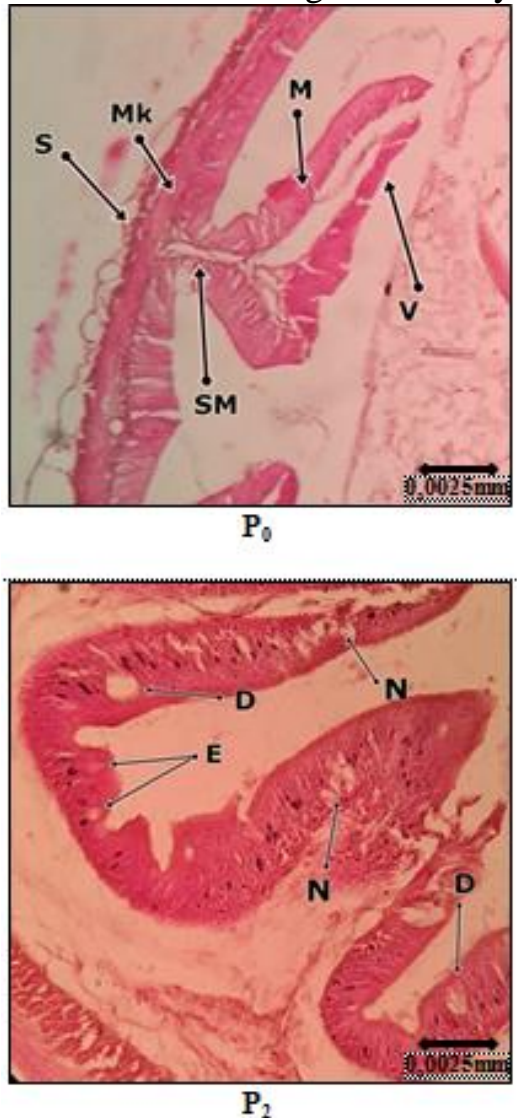

Rhizophoracee, komponen utamanya adalah senyawa tanin. Tanin pada penggunaan konsentrasi tinggi bertindak sebagai toksin bagi plasma untuk merusak sistem dinding sel. Menurut Pratiwi dan Manan (2015) usus adalah organ yang sering terpapar oleh agenagen patogen dan parasit. Agen-agen tersebut masuk ke dalam usus melalui makanan yang masuk ke dalam saluran pencernaan.
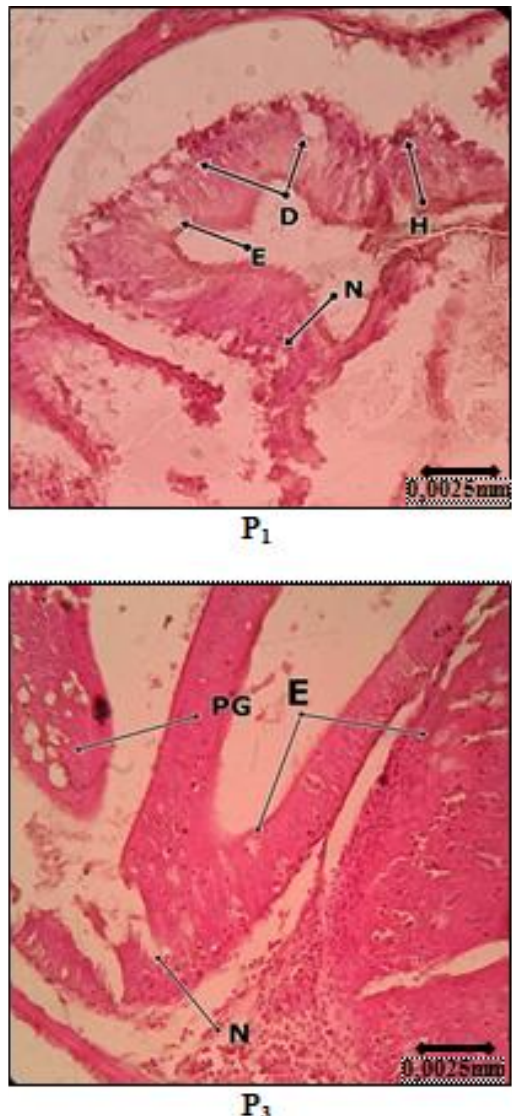

\section{Gambar 3. Fotomikrogaf Struktur Usus Ikan Jambal Siam (P. hypophthalmus); Pewarnaan} HE (Perbesaran 400X)

Keterangan: $\mathrm{P}_{0}=$ Pemberian pakan tanpa tambahan ekstrak daun $R$. apiculata $; \mathrm{P}_{1}=1.5 \mathrm{mg} / \mathrm{Kg}$ pakan; $\mathrm{P}_{2}=1.7$ $\mathrm{mg} / \mathrm{Kg}$ pakan; $\mathrm{P}_{3}=1.9 \mathrm{mg} / \mathrm{Kg}$ pakan. V (Villi usus); M (Mukosa Usus); SM (Sub Mukosa); Mk (Muskularis); S (Lapisan Serosa); H (Hemoragi); E (Edema); N (Nekrosis); PG (Proliferasi Sel Goblet); D (Degenarasi Vakuola).

\section{Kesimpulan dan Saran}

Berdasarkan hasil pengamatan pada struktur jaringan hati dan usus ikan jambal siam, maka disimpulkan bahwa pemberian pakan mengandung ekstrak daun $R$. apiculata mempengaruhi perubahan struktur histologi hati dan usus ikan jambal siam. Perubahan yang terjadi pada hati ikan yaitu $\mathrm{P}_{1}$ mengalami hemoragi, $\mathrm{P}_{2}$ mengalami hemoragi dan hipertropi, $\mathrm{P}_{3}$ mengalami kerusakan hemoragi, hipertropi dan nekrosis. Usus ikan juga mengalami perubahan struktur berupa hemoragi, edema, proliferasi sel goblet, degenerasi vakuola dan nekrosis. Hasil terbaik dari penambahan ekstrak daun $R$. apiculata terhadap struktur jaringan hati dan usus ikan adalah dosis $1,5 \mathrm{mg} / \mathrm{Kg}$ pakan. Keadaan kualitas air pada media pemeliharaan berada pada kondisi normal, yakni suhu $28-29.5^{\circ} \mathrm{C}$; pH 6,1-6,8; DO 6,4-6,9ppm; dan $\mathrm{NH}_{3}$ 0,04$0,08 \mathrm{ppm}$. 
Berdasarkan hasil penelitian yang telah dilaksanakan, maka disarankan untuk menambahkan ekstrak daun $R$. apiculata ke dalam pakan dengan dosis $1,5 \mathrm{mg} / \mathrm{Kg}$ pakan namun dengan jangka waktu pemberian yang lebih singkat untuk menjaga kesehatan ikan dan juga disarankan untuk melakukan penelitian pada jenis ikan lain.

\section{Daftar Pustaka}

Andayani, S., S. Heny, dan M. Ifatul. (2018). Pengaruh Pemberian Ekstrak Kasar Kulit Buah Naga (Hylocereus costaricensis) terhadap Histopatologi Hati Ikan Nila (Oreochromis niloticus) yang Terinfeksi Aeromonas hydrophila. J. Fisheries and Marine Research, 3(2):149-159

Apriyanto, H., E. Harpeni, A. Setyawan, dan Tarsim. (2014). Pemanfaatan ekstrak buah Rhizophora sp. sebagai Antibakteri terhadap bakteri pathogen ikan air tawar. Jurnal Rekayasa dan Teknologi Budidaya Perairan 3(1): 290-296.

Arnanda, Q.P. dan F.N. Rina. (2019). Penggunaan Radiofarmaka Teknesium99m dari Senyawa Glutation dan Senyawa Flavonoid sebagai Deteksi Dini Radikal Bebas Pemicu Kanker. J. Farmaka, 17(2): 234-243

Asniatih., I. Muhammad, dan S. Kabir. (2013). Studi Histopatologi pada Ikan Lele Dumbo (Clarias gariepinus) yang Terinfeksi Bakteri Aeromonas Hydrophila. J. Mina Laut Indonesia, 3(12): 13-21.

Atmoko, T. dan M. Amir. (2009). Toxicity Testing and Phytochemical Screening of Orangutan Food Extracts to Larvae of Artemia salina L. J. Penelitian Hutan dan Konservasi Alam, 6(1): 3745.

Berawi, K.N., dan M. Desty. (2018). Efektivitas Kulit Batang Bakau Minyak (Rhizopora apiculata) sebagai Antioksidan. J. Agromedicine 5(1): 412-417.

Ciptaningrum, I. dan A.P. Reyhan. (2019). Efek Antimikroba Rhizophora apiculata untuk Menghambat Pertumbuhan Bakteri. J. Farmasetis, 8(2): $75-82$.
Darlian, L., G. Imran, dan Fachrudin. (2011). Skrining Bioaktivitas Ekstrak Kulit Akar Bakau Merah (Rhizophora apiculata bl) terhadap Daya Hambat Pertumbuhan Koloni Bakteri Streptococcus sp. Jurnal Prog.Kim. SI 1(2): 73-82.

Dewi, E. (2018). Pengaruh Perendaman Ekstrak Buah Mengkudu Morinda citrifolia terhadap Histopatologi Organ Insang dan Hati Ikan Nila Oreochromis niloticus. Skripsi. Universitas Airlangga.

Diba, D.F., dan E.R. Wildan. (2018). Gambaran Histopatologi Hati, Lambung dan Usus Ikan Cakalang (Katsuwonus pelamis) yang Terinfestasi Cacing Endoparasit. J. Octopus 7(2): 24-30.

Ismaya, R., Rosmaidar, dan Nazarudin. (2017). Pengaruh Paparan Timbal $(\mathrm{Pb})$ Terhadap Histopatologis Usus Ikan Nila (Oreochromis nilloticus). JIMVET, 2(1): 12-16.

Jamin, dan Erlangga. (2016). Pengaruh Insektisida Golongan Organofosfat Terhadap Benih Ikan Nila Gift (Oreochromis niloticus, Bleeker): Analisis Histologi Hati dan Insang. J.Acta Aquatica, 3(2): 46-53.

Juanda, S.J., dan I.E. Sri I.E. (2018). Histopatologi Insang, Hati dan Usus Ikan Lele (Clarias gariepinus) di Kota Kupang, Nusa Tenggara Timur. $J$. Saintek Perikanan, 14(1): 23-29.

Kahfi, K.E. (2016). Histopatologi Hati dan Ginjal Ikan Lele Dumbo (Clarias gariepinus) yang Diberi Pakan Simplisia Kulit Buah Manggis (Garcinia mangostana L). Skripsi. Fakultas Perikanan dan Ilmu Kelautan. Pekanbaru: Universitas Riau.

Marlinda, M., S.S. Meiske, dan D.W. Audy. (2012). Analisis Senyawa Metabolit Sekunder dan Uji Toksisitas Ekstrak Etanol Biji Buah Alpukat (Persea americana Mill.). J. MIPA UNSRAT online, 1(1): 24-28

Nazarudin, Z., M. Izzati, dan F. Ika. (2017). Segmentasi Citra untuk Menentukan Skor Kerusakan Hati Secara Histologi. Seminar Nasional Informatika Medis, 8: 15-21. 
Permana, R. (2009). Studi Histopatologi pada Ikan Arwana Super Red Scleropages formosus. Skripsi. Fakultas Perikanan dan Ilmu Kelautan. Institut Pertanian Bogor, Bogor.

Pratiwi, H.C. dan A. Manan. (2015). Teknik Dasar Histologi pada Ikan Gurami (Osphronemus gouramy). Jurnal Ilmiah Perikanan dan Kelautan, 7 (2): 153157.

Ramalingam V, dan R. Rajaram. (2018). Enhanced antimicrobial, antioxidant and anticancer activity of Rhizophora apiculata: an experimental report. Biotech 8:1-13.

Redha, A. (2010). Flavonoid: Struktur, Sifat Antioksidatif dan Peranannya dalam Sistem Biologis. J. Belian, 9 (2): 196 202

Riauwaty, M. (2012). Histopatologi Hati dan Ginjal Ikan Patin (Pangasius hypopthalmus) yang Terinfeksi Aeromonas hydrophila dan Diobati dengan Temulawak (Curcuma xanthorrhiza ROXB.). Fakultas Perikanan dan Ilmu Kelautan. Universitas Riau

Rohaeti, E., I. Batubara, A. Lieke, dan L.K. Darusman. (2010). Potensi Ekstrak Rhizophora sp. Sebagai Inhibitor Tirosinase. Prosiding Semnas Sains 3: 196-201

Safratilofa. (2017). Histopatologi Hati dan Ginjal Ikan Patin (Pangasionodon hypopthalmus) yang Diinjeksi Bakteri Aeromonas hydrophila. Jurnal Akuakultur Sungai dan Danau. 2(2): 83-88.

Sohrabnezhad, M., M. Sudagar, dan M. Mazandarani. (2017). Effect of Dietary Soybean Meal and Multienzyme on Intestine Histology of Beluga Sturgeon (Huso huso). International Aquatic Research 9: 271-280.
Suciati, A., Wardiyanto, dan Sumino. (2012). Efektifitas Ekstrak Daun Rhizophora mucronata dalam Menghambat Pertumbuhan Aeromonas salmonicida dan Vibrio harveyi. e-Jurnal Rekayasa dan Teknologi Budidaya Perairan 1(1): 1-8.

Sukarni, M. dan N. Happy. (2012). Kajian Penggunaan Ciprofloxacin terhadap Histologi Insang dan Hati Ikan Botia (Botia macracanthus, Bleeker) yang Diinfeksi Bakteri Aeromonas hydrophila. J.Exp. Life Sci, 2 (1): 6-12.

Syawal, H., H. Alawi, N. Asiah, dan Yuharmen. (2018). Penambahan Ekstrak Daun Mangrove Rhizophora sp. ke dalam Pakan untuk Meningkatkan Kesehatan Ikan terhadap Penyakit Bakterial. Laporan Penelitian. Universitas Riau.

Winarsih, W., W. Ietje, P.S. Nova, dan W. Istifharany. (2012). Uji Toksisitas Akut Ekstrak Rimpang Kunyit pada Mencit : Kajian Histopatologis Lambung, Hati dan Ginjal. J. Veteriner, 13(4):402-409.

Windarti., A.H. Simarmata, dan Eddiwan. (2017). Buku Ajar Histologi. UR press: Pekanbaru.

Wiranatha, I.G., S. Iriani, dan I.W. Ngurah. (2019). Histopatologi serta Aktivitas Hati Kelinci Lokal (Lepus sp.) yang Diberi Ransum Tepung Daun Kaliandra (Calliandra calothyrsus Meissn.) dan Kulit Nanas (Ananas comosus L.). Metamorfosa: Journal of Biological Sciences, 6(2): 183-190.

Yanti, M. (2018). Histopatologi Ginjal dan Hati Benih Ikan Kakap Putih (Lates calcarifer Bloch) yang Diinjeksi dengan Lima Isolat Bakteri yang Berbeda. Skripsi. Fakultas Perikanan dan Ilmu Kelautan. Institut Pertanian Bogor. 